\title{
PENYEBAB, DAMPAK, DAN MANAJEMEN PENYAKIT KARANG DI EKOSISTEM TERUMBU KARANG
}

\author{
Ofrijohan \\ Pusat Penelitian dan Pengembangan Perikanan Budidaya \\ Jl. Ragunan 20, Pasar Minggu, Jakarta Selatan 12540 \\ E-mail: ofrijohan@ cria.indosat.net.id
}

\begin{abstract}
ABSTRAK
Penelitian tentang penyakit karang sudah berkembang dan banyak peneliti yang menekuninya di negara asing, namun berbeda dengan di negara Indonesia yang merupakan negara kepulauan dan sebagian besar pulaunya memiliki karang, malah belum ada penelitian dan data tentang penyakit karang, kalaupun ada baru dimulai pada 1 atau 2 lokasi dengan peneliti yang menekuni 1 atau 2 orang saja se-Indonesia. Berbagai faktor lingkungan sebagai penyebab terjadinya penyakit karang di antaranya disebabkan oleh faktor abiotik yaitu oleh stres temperatur, sedimentasi, zat kimia, nutrien tidak seimbang, radiasi ultra-violet, dan faktor biotik seperti predasi, kompetisi dengan alga, dan terinfeksi penyakit. Banyak informasi yang akan dibahas pada tulisan ini sebagai pengantar untuk memahami penyakit karang di antaranya tentang faktor penyebab, jenis, dan dampak penyakit, penelitian di Indonesia, dan manajemen serta pengelolaan yang perlu dilakukan apabila terjadi serangan penyakit di suatu ekosistem terumbu karang.
\end{abstract}

KATA KUNCl: Jenis penyakit karang, faktor abiotik, terumbu karang

\section{PENDAHULUAN}

Penyakit karang didefinisikan sebagai sesuatu kegagalan fungsi vital hewan karang, organ, atau sistem, termasuk interupsi, penghentian pertumbuhan dan perkembangbiakan, atau kegagalan fungsi lain, penyebabnya bisa berasal dari sumber biotik atau abiotik (Stedman's Medical Dictionary, 1982). Sementara karang sehat adalah suatu kondisi hewan karang di mana fungsi anggota tubuhnya dapat berfungsi secara optimal tanpa adanya penyakit atau keadaan yang tidak normal. Kerusakan karang dapat disebabkan oleh dua faktor yaitu faktor abiotik (stres temperatur, sedimentasi, zat kimia, nutrien tidak seimbang, radiasi ultra-violet) dan faktor biotik (predasi, kompetisi dengan alga, terinfeksi penyakit). Sementara penyakit karang dapat dicirikan oleh beberapa hal di antaranya; 1) kelompok yang dapat diidentifikasi tanda-tandanya (teramati anomali yang mengindikasikan adanya penyakit), dan/atau 2) diketahui etiologi atau pembawa penyebab, dan/atau 3) terjadi perubahan struktur secara konsisten (seperti perkembangan yang tidak wajar, perubahan komposisi sel atau morfologi dan tumor) (Peter, 1997).

Penyakit yang disebabkan oleh faktor biotik, agen etiologinya adalah makhluk hidup seperti patogen atau parasit. Banyak organisme yang hidup berasosiasi atau bersimbiosis dengan organisme lain, di antaranya ada yang bersimbiosis mutualisme (saling menguntungkan) di mana organisme mendapatkan nutrisi dari tubuh inangnya. Jika parasit dapat menyebabkan penyakit dan kematian pada tubuh inangnya misalnya adanya virus, bakteri, jamur, dan protozoa (dikenal mikroparasit) serta metazoan seperti cacing helminthes dan arthtopods (makroparasit) (Peter, 1997). Penyakit yang disebabkan oleh faktor abiotik di mana semua struktur dan fungsi tubuh yang rusak disebabkan oleh adanya tekanan faktor lingkungan seperti perubahan kondisi fisik (salinitas, temperatur, intensitas cahaya atau panjang gelombang, sedimentasi, konsentrasi oksigen dan arus) atau ekspos dari bahan kimia beracun (seperti logam berat dan bahan organik seperti tumpahan minyak atau pestisida) (Peter, 1997).

Karang yang mengalami infeksi penyakit akan terlihat ada bagian koloninya yang mengalami lesion atau ada perbedaan band dari jaringan karang (tissue) yang hilang, hal ini dapat disebabkan oleh bakteri, virus, protozoa, atau jamur. Kehilangan jaringan karang akibat penyakit ini dapat menyebabkan beberapa gangguan di antaranya adalah gangguan dalam bereproduksi, penurunan rata-rata pertumbuhan, perubahan struktur komunitas, penurunan keanekaragaman spesies, dan kelimpahan asosiasi hewan laut di terumbu karang (Loya et al., 2001). Penyakit karang banyak dilaporkan dapat merusak karang dalam skala besar seperti yang terjadi di Laut Caribbean (Croquer et al., 
2003), Australia dan beberapa lokasi di negara luar. Dampak penyakit karang di perairan Indonesia belum ada yang melaporkan, hal ini mungkin karena kurangnya penelitian secara spesifik terhadap penyakit karang tersebut.

\section{Faktor Penyebab Penyakit Karang}

Beberapa faktor lingkungan penyebab terjadi penyakit karang di antaranya adalah faktor abiotik seperti kenaikan temperatur, sedimentasi, sinar ultraviolet, logam berat, dan bahan kimia dari kegiatan budidaya. Sementara dari faktor biotik seperti bakteri, virus, jamur, atau protozoa dan juga karena cacing dan arthropoda (Yomashiro, 2004).

\section{Temperatur (suhu)}

Pada abad ke-20 ini rata-rata kenaikan temperatur $1^{\circ} \mathrm{C}$ merupakan kenaikan yang terbesar sejak 1.000 tahun dan para ahli meterologi memprediksi kenaikan akan lebih tinggi lagi pada abad ini (Bijlsma et al., 1995).

Beberapa penelitian berhasil mengungkapkan bahwa pemanasan global merupakan faktor penting yang mempengaruhi kehidupan hewan karang, karena sempitnya rentang toleransi terhadap suhu $\left(18^{\circ} \mathrm{C}-30^{\circ} \mathrm{C}\right)$ sehingga hewan karang mudah mengalami stres terhadap perubahan suhu. Jika stres ini terjadi akan ditemukan tanda bahwa karang akan mengalami pemutihan (bleach), di mana terjadi kehilangan alga yang bersimbiosis dengan hewan karang yang dikenal dengan zooxanthellae. Kejadian kematian massal karang akibat kenaikan atau penurunan suhu pernah terjadi pada tahun 1997/1998 pada beberapa negara termasuk Indonesia. Pada daerah Carribbean perubahan suhu pada tahun 2005 diikuti dengan munculnya penyakit karang yaitu white plaguedan yellow blotch (Millert et al., 2006).

Pola musiman penyebaran penyakit karang di bagian Northeastern Carribean mendukung bahwa terdapat hubungan yang kuat antara pemanasan air laut dengan kerusakan karang karena penyakit karang. Kematian karang yang baru muncul dari 2 virus dan penyakit yang berbahaya yaitu white plague dan yellow band, telah berkembang semasa musim suhu tertinggi selama 4 tahun sebelumnya di terumbu karang Puerto Rico dan di Kepulauan US Virgin. Kejadian ini diikuti oleh kejadian secara tiba-tiba peristiwa pemutihan massal tahun 2005, tercatat sebagai peristiwa yang mematikan banyak karang di Northeastern Carribean, terserang oleh penyakit white plague, yellow band, dan white patch, serangan penyakit ini lebih intensif pada daerah ini dan beberapa kematian berlanjut hingga 2007 (Raymundo et al., 2008).
Pada daerah Great Barrier Reef, penyebaran penyakit karang meningkat dari musim dingin hingga musim panas pada semua famili karang. Penyebaran penyakit karang meningkat 15 kali pada karang jenis Acroporidae, 12 kali pada karang Faviidae dan 2 kali pada Pocilloporidae pada survai di musim panas. Kemudian keberadaan tiga jenis penyakit karang meningkat sangat nyata pada musim panas yaitu pengikisan bagian skeleton meningkat lebih dari dua kali lipat, black band dan infeksi cyanobacterial lebih dari tiga kali lipat, dan white syndrome lebih dari 50 kali lipat kejadian.

Pada pengamatan lebih jauh pada hubungan antara temperatur dilakukan survai keberadaan penyakit karang di kawasan Great Barrier Reef. Pada tahun 1998 AIMS (Australian Institute of M arine Science) melakukan Program Long-term Monitoring mulai melakukan monitor white syndrome (WS) yang terjadi pada lebih 15 jenis karang termasuk karang Acropora tabulate. Peneliti dengan melakukan survai pada 47 lokasi terumbu karang dari tahun 1998 sampai 2004 untuk mengetahui dampak dari WS. Dengan menggunakan data mingguan sepanjang 4 km dari temperatur dari NOAA AVHRR Pathfinder, diketahui terdapat hubungan yang sangat nyata antara temperatur dan penyakit karang (Raymundo et al., 2008).

Hubungan antara terjangkitnya atau peningkatan penyebaran dan panasnya temperatur telah terdeteksi bagi penyakit black band, aspergillosis, yellow band disease, white patch disease, dan white syndrome (Raymundo et al., 2008).

Peningkatan temperatur juga dapat berdampak pada proses biologi dan fisik karang, khususnya kemampuan melawan infeksi penyakit menjadi berkurang, dengan demikian akan mempengaruhi keseimbangan antara potensi patogen dan host (Rosenberg \& Ben-Haim, 2002). Patogen akan bisa menjadi mematikan pada suhu lebih tinggi (Ben Haim et al., 2003a; 2003b).

Pada tumbuhan normal, sama dengan karang, memiliki lapisan mocus yang dapat melindungi serangan patogen; gangguan ini dapat menyebabkan terjadinya penyakit karang (Ritchie, 2006).

Pada saat terjadi bleaching pada karang akibat perubahan suhu, karang akan mengeluarkan zooxanthella yang bersimbiosis dengan karang pada lapisan endodermnya. Karang akan mengeluarkan zooxanthella selama terjadi kenaikan suhu $1^{\circ} \mathrm{C}-2^{\circ} \mathrm{C}$ di atas suhu normal, pada akhirnya akan tejadi kehilangan pigmen dan berbahaya terhadap proses fotosintesis atau dalam respons terhadap perubahan salinitas, bahan kimia dari penangkapan menggunakan racun atau adanya sedimentasi. 


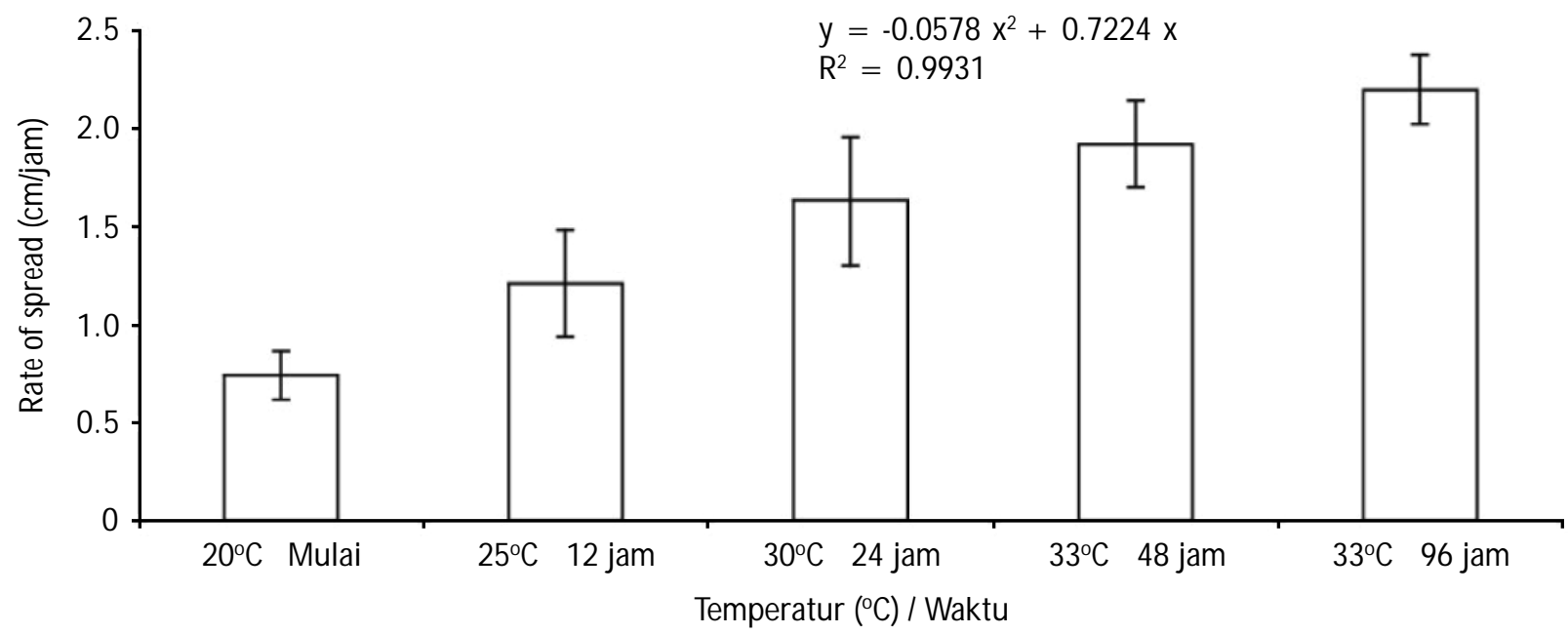

Gambar 1. Perkembangan luka (lesion) setelah diinokulasi dengan penyakit YB (Yellow Band Disease) dengan meningkatkan suhu dalam eksperimen di akuarium (Sumber: Cervino et al., 2004)

Pada Gambar 1 terlihat kondisi karang setelah diinokulasi dengan penyakit YB kemudian diamati dampaknya setiap beberapa jam berikutnya. Terlihat bahwa luasan terinfeksi dan luka akibat YBD semakin luas dengan bertambahnya waktu (jam) dan meningkatnya suhu perairan. Sehingga dapat diperkirakan kalau terjadi pada suatu koloni akan bisa menyebar ke seluruh permukaan koloni karang hingga bisa berakibat kematian. Kalau hal ini terjadi pada beberapa koloni di suatu perairan tentu dapat membunuh hamparan luas karang di daerah tersebut, seperti banyak terjadi di beberapa wilayah.

Hasil penelitian pada bagian timur laut Mediterranean, karang jenis Oculina patagonica sebelum terinfeksi oleh Vibrio shiloi diawali dengan peristiwa bleaching di mana temperatur perairan mendekati maksimum $29^{\circ} \mathrm{C}-30^{\circ} \mathrm{C}$.

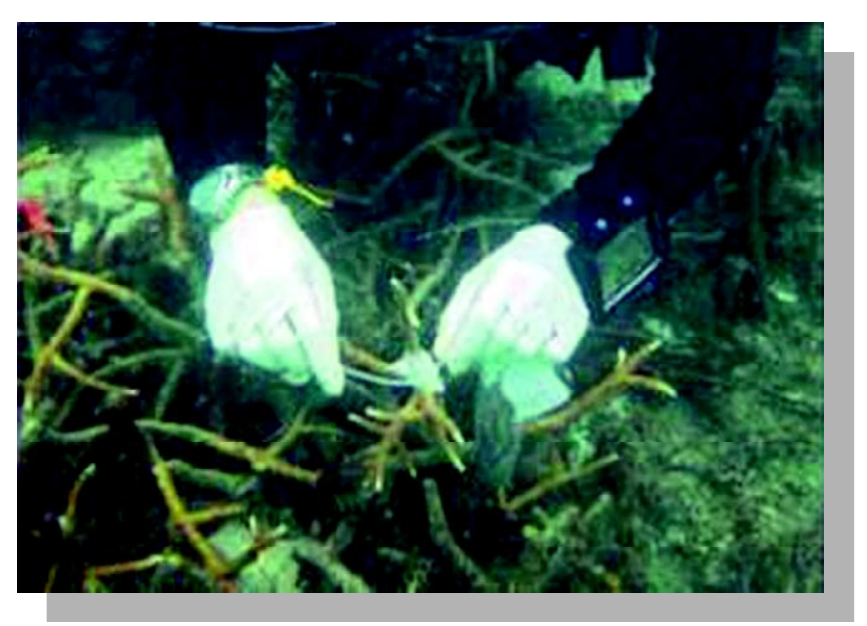

Gambar 2. Penelitian inokulasi bakteri penyebab penyakit pada karang bercabang Acropora cervicornis (Sumber: Gil-Agudelo et al., 2006)
Di samping penelitian skala laboratorium, penelitian inokulasi penyakit karang bisa dilakukan pada karang di alam (Gambar 2) dan perkembangan dampaknya berlangsung dalam hitungan hari seperti pada Gambar 3.

\section{Kualitas Perairan}

Seiring bertambahnya jumlah penduduk, nutrien, masuknya sedimen dari daratan, polusi dan bahkan patogen dapat masuk ke perairan yang banyak terdapat komunitas hewan dasar termasuk karang. Sementara hubungan antara stres antropogenik dan keberadaan penyakit masih belum banyak dipahami, satu hipotesis di mana penyakit karang difasilitasi oleh menurunnya kualitas perairan khususnya karena eutrofikasi dan sedimentasi. Kondisi ini sangat membutuhkan prioritas manajemen untuk memahami hubungan antara kualitas perairan dan infeksi penyakit karang, karena faktor lokal ini yang dapat diharapkan dari suatu manajemen (Raymundo et al., 2008).

Meskipun karang dapat tumbuh pada perairan yang memiliki nutrien tinggi, kejadian terbaru menemukan bahwa terdapat efek sinergi antara nutrien dan penyakit karang. Nutrien tinggi (N, P) berasosiasi dengan kecepatan tanda infeksi penyakit dari yellow band disease dan aspergillosis di lapangan dan black band disease. Meskipun nutrien yang tinggi tersebut tidak berasosiasi dengan kehilangan jaringan pada karang yang sehat. Kondisi yang konsisten ini ditemukan oleh Kuntz et al. (2005) yang mengamati kecepatan pelepasan jaringan karang pada karang sehat terekspos terhadap sumber karbon, tetapi kombinasi karang terinfeksi dan jumlah nutrien meningkatkan rata-rata penyakit dari syndrome. Hal ini belum jelas apakah pengaruhnya karena tubuh inang 


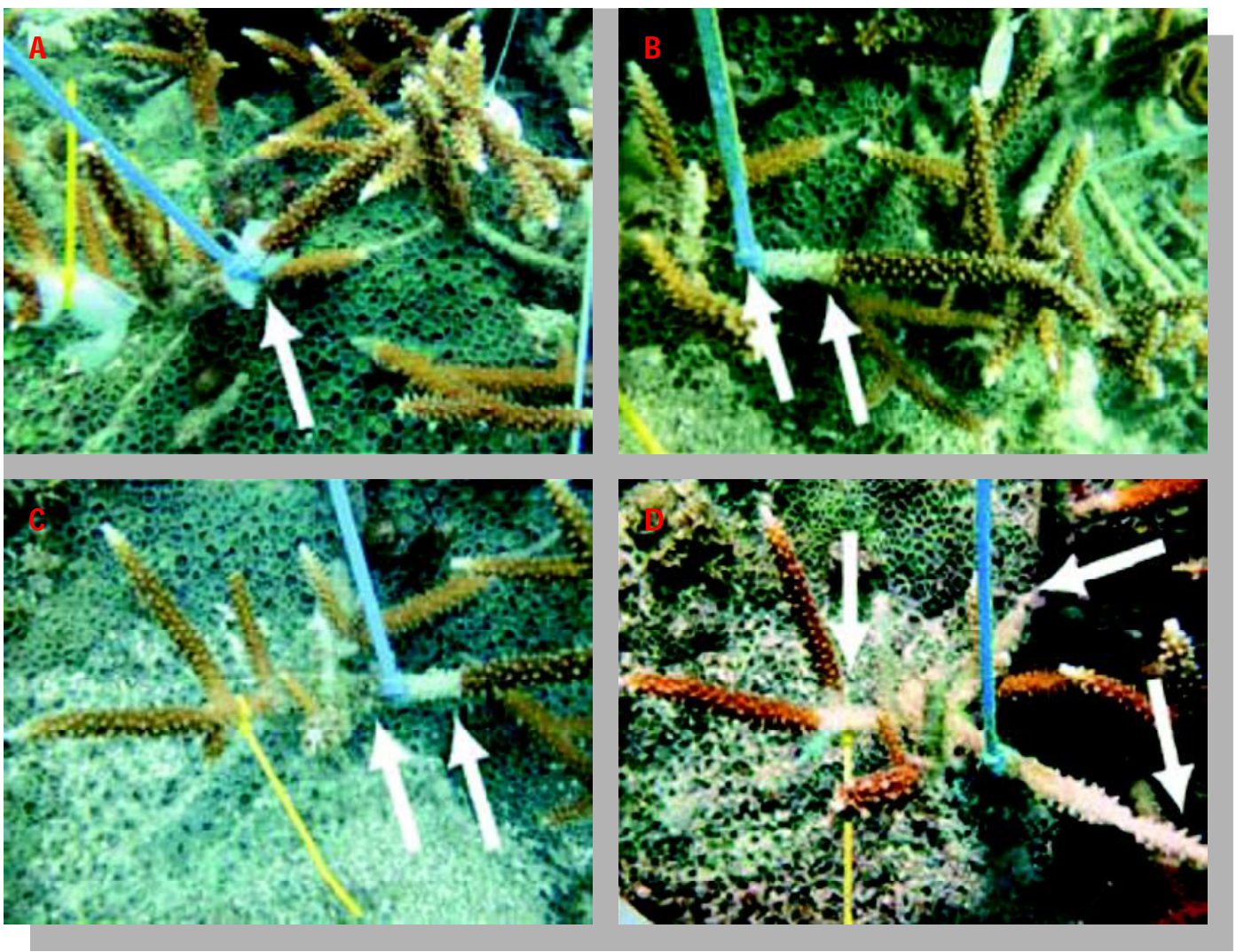

Gambar 3. Perkembangan penyakit karang White Band Disease Type II yang diinokulasikan pada karang A. cervicornis. A) hari 0 ; b) hari 2; c) hari 7; dan d) hari 17. Panah menunjukkan batas perkembangan penyakit (Sumber: Gil-Agudelo et al., 2006)

yang terinfeksi resisten atau memiliki positif efek dari pertumbuhan patogen atau virus.

Sedimentasi membuat tantangan lain terhadap daya tahan inang penyakit. Dampak dari sedimentasi yang berasal dari daratan pada komunitas pantai adalah banyak ditemukannya kelompok karang yang mengalami kematian, bagian skeleton yang terekspos dibatasi dengan bagian karang yang masih sehat. Sementara bagian jaringan karang yang mati diasumsikan sebagai hasil langsung dari gangguan, mikroba juga bisa berkontribusi. Sedimen dapat berasosiasi dengan bakteri sebagai penyebab terjadinya necrosis pada karang yang rusak karena sedimen, sebagai antibiotik menurunkan jumlah bagian jaringan karang yang rusak akibat endapan sedimen. Barubaru ini, oppurtunis pathogen terrestrial (jamur tanah Aspergillus sydowii dan enterobakterium (Serratia marcescens) telah didemonstrasikan sebagai agen penyebab pada dua penyakit baru-baru ini menyerang banyak karang di Carribean. Dengan demikian, sedimen dari daratan tidak hanya menyebabkan stres fisik pada perairan dangkal, organisme bentik seperti karang, tetapi juga sebagai pathogen reservoir.
Pada beberapa kejadian dapat disimpulkan bahwa stres anthropegenik dapat berkaitan dengan beberapa penyakit karang. Dengan demikian sangat penting membentuk manajemen terumbu karang dan penggunaan lahan secara praktis. Tantangan ini terletak dalam mencari hubungan yang komplek dari bermacam sumber penyebab terjadinya stres yang memicu terjadinya penyakit karang.

\section{Jenis dan Dampak Penyakit Karang}

\section{Penyakit Disebabkan Bakteri}

Salah satu jenis penyakit karang yaitu white pox, pernah menyebar dan telah membunuh karang sekitar 90\%karang bercabang Acropora palmata di terumbu karang Caribbean sehingga jenis karang ini menjadi spesies yang hampir punah. Kematian karang rata-rata mencapai $10 \mathrm{~m}^{2} / \mathrm{hari}$ yang disebabkan oleh bakteri Serratia marcescens (Patterson et al., 2002) dalam (Yamashiro, 2004). Bakteri Serratia ini ternyata juga menyerang manusia tepatnya pada usus dan banyak pasien di rumah sakit menderita karena bakteri ini. Virus vibrio (Vibrio AK-1) juga telah ditemukan dapat membunuh dengan cepat jaringan karang Oculina patagonica dengan kecepatan beberapa sentimeter per 
hari (Kushmaro et al., 1996 dalam Yamashiro, 2004). Kemudian jenis karang Octocorallia (Gorgonia ventalina) mengalami kematian di Caribbean karena adanya jamur yang pada umumnya sering ditemukan di tanah yaitu Aspergillus sydowii (Geiser et al., 1998 dalam Yamashiro, 2004).

Baru-baru ini ditemukan pula jenis penyakit baru yaitu Porites Ulcerative White Spot (PUWS) yang teridentifikasi pada karang jenis Porites di lautan Indian dan Pasifik (Raymundo et al., 2003). Ukuran diameter koloni awal 3-5 mm dapat terinfeksi hingga mati semua bagian koloni tersebut.

Kematian karang akibat terinfeksi oleh bakteri banyak dilaporkan hingga saat ini dan ternyata penelitian ini sudah berkembang sejak tahun 1990. Implikasi kerusakan lingkungan laut dan diikuti menurunnya sistem daya imun karang dan akhirnya terjangkit penyakit disebabkan oleh adanya bakteri (Yamashiro, 2004).

\section{Tumor pada Karang}

Ciri lain dari karang mengalami penyakit di antaranya adalah karang terserang tumor dapat terlihat ciri-ciri seperti ada bagian polip karang dalam satu koloni memiliki pertumbuhan lebih cepat dari bagian yang lain (hyperplasia) dan tumor (seperti neoplasm; pertumbuhan yang tidak normal dari jaringan bagian koloni karang, mutation; perubahan bentuk).

Tumor pada karang biasanya muncul berupa gumpalan pada bagian koloni karang dengan densitas zooxanthella lebih rendah dari bagian koloni yang sehat. Tumor tumbuh pada bagian tubuh karang tetapi tidak membunuh koloni. Namun pada bagian koloni yang bertumor akan mengalami penurunan jumlah polip dan fekunditas, hal inilah yang menjadi indikasi bahwa koloni karang terinfeksi karang. Kemudian karakteristik terakhir dari karang yang terserang tumor adalah tentakel tidak muncul dan morfologi dari spesies karang tersebut hilang pada bagian yang ada tumornya (Yamashiro, 2004).

Karang yang memiliki tumor akan lebih sensitif terhadap perubahan lingkungan seperti kenaikan suhu sehingga lebih cepat mati dibandingkan dengan karang yang berkondisi sehat. Kemudian karang yang bertumor juga mengalami penurunan kapasitas reproduksinya. Analisis kandungan lemak (simpanan kelebihan makanan berupa energi) dari ekstrak dengan membandingkan bobot lemak yang diekstrak per bobot kering dari jaringan dalam persentase diperoleh 32,2\%pada jaringan normal dan 10,6\%pada jaringan yang memiliki tumor. Pernyataan ini sangat mendukung sekali bahwa karang yang bertumor akan mengalami tingkat reproduksi (oogenesis) yang menurun karena untuk proses oogenesis karang membutuhkan lemak dalam jumlah yang sangat besar. Dengan demikian juga semakin meningkatnya kepekaan tumor terhadap suhu air yang tinggi akan lebih dekat dengan semakin rendahnya kemampuan karang untuk menyimpan lemak sebagai cadangan energi di dalam tubuhnya, di mana lemak sangat dibutuhkan dalam proses metabolisme dan energi tambahan disaat stres.

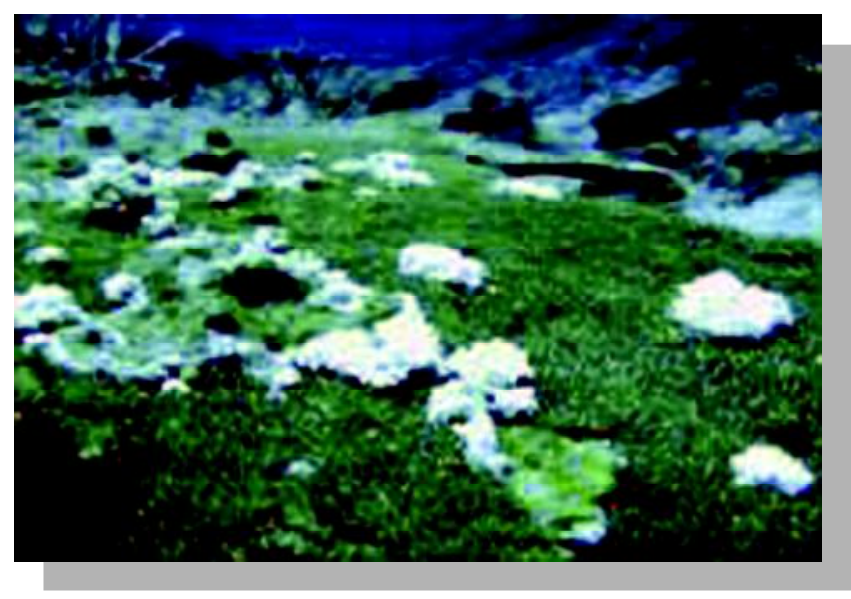

Gambar 4. Ditemukan tumor pada Acropora sp. jenis Tabulate (karang meja) di Pulau KeramaOkinawa (Foto: A. Irikawa dalam Yamashiro, 2004)

\section{Penyakit Disebabkan Cacing}

Penyakit karang juga dapat disebabkan oleh cacing yang dikenal dengan Porites Pink Block Disease (PPBD), di lapangan sangat mudah mengenalnya karena permukaan koloni dicirikan berwarna pink. Penelitian di Hawaii ditemukan cacing Trematoda Podocotyloides sebagai parasit di polip karang. Sebenarnya cacing ini juga hidup di kekerangan (bibalve), koral dan ikan (ikan kepe-kepe, Chaetodon). Penyakit ini dapat menyebabkan penurunan rata-rata pertumbuhan mencapai 50\%(Aeby, 1992). Karang akan mengalami penurunan kandungan zooxanthella.

Kecepatan hilangnya jaringan karang akibat penyakit karang mulai dari bagian dasar koloni sampai ke atas bekisar $3 \mathrm{~mm}$ sampai $2 \mathrm{~cm}$ per hari (Goreau et al., 1998, Richardson, 1998).

Beberapa penyebab penyakit karang yang pernah dilaporkan seperti terjadi pada karang Oculina patagonica disebabkan oleh Vibrio shiloi; black band disease disebabkan oleh microbial consortium; penyakit pada sea-fan (aspergillosis) disebabkan Aspergillus sydowii; dan white plague disebabkan oleh Sphingomonas sp., dan pemutihan pada karang Pocillopora damicornis di Laut Merah 
disebabkan oleh Vibrio coralyticus. Pada kasus pemutihan karang yang disebabkan oleh V. Shiloi sebagian besar disebabkan oleh adanya peningkatan temperatur.

\section{Penelitian Penyakit Karang di Indonesia}

Penelitian penyakit karang di Indonesia belum banyak dilaporkan, demikian juga pada lokasi pemantauan karang secara rutin juga tidak pernah melaporkan dampak yang besar terhadap penyakit karang. Penelitian yang baru dirintis misalnya dilakukan oleh lembaga Yayasan Terumbu Karang Indonesia (Terangi) yang dilaksanakan di Kepulauan Seribu, Jakarta. Penelitian baru bersifat pemantauan di lapangan dan belum secara detail mengatahui penyebab dan agen pembawa penyakit tersebut. Di samping itu, juga telah ada penelitian yang dirintis oleh dosen dari Universitas Dipenegoro, Semarang, namun belum berkembang seperti yang ada di lembaga peneliti asing.

Penelitian lain juga pernah dilakukan di perairan Provinsi Manado oleh peneliti asing, hasilnya dapat dilihat pada publikasi international. Secara spesifik lembaga penelitian di Indonesia belum pernah melakukan penelitian yang lebih mendalam terhadap penyakit karang di Indonesia sampai saat ini.

Pada Gambar 5 terlihat jenis karang Montipora sp. terserang oleh penyakit BBD, pada kasus ini bagian yang diserang dimulai dari tengah koloni kemudian menyebar merata ke semua bagian koloni, terlihat bagian putih adalah bagian koloni yang baru saja mati, bagian yang putih beralga adalah bekas serangan yang agak lebih lama (4-7 hari) dan sedangkan bagian pinggir yang berwarna

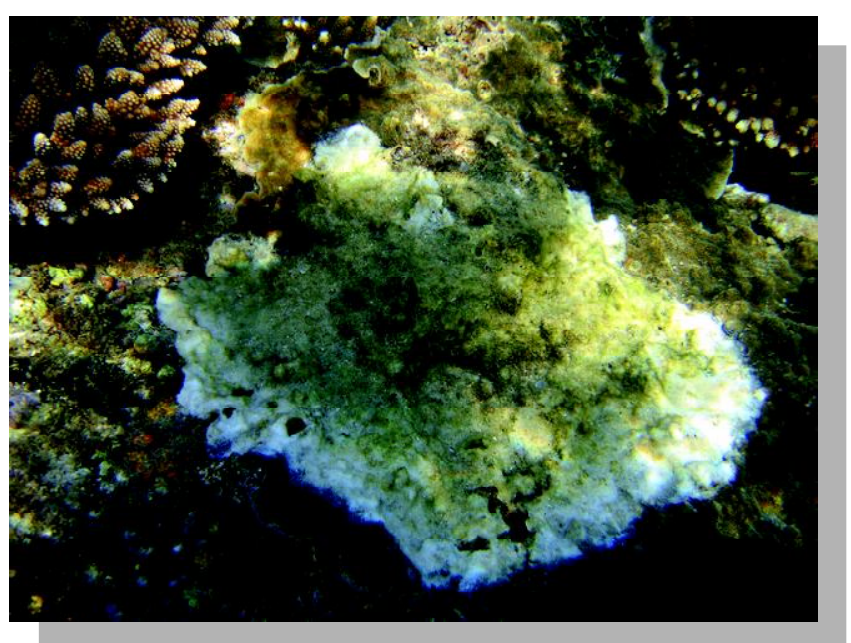

Gambar 5. Karang Montipora sp. bentuk life form folious terserang oleh penyakit black band disease (BBD) di Pulau Pari, Kepulauan Seribu (Foto: Ofri Johan) garis hitam adalah bagian koloni yang sedang diserang penyakit BBD tersebut. Serangan penyakit BBD ini merupakan pertama kali penulis temukan di kawasan Kepulauan Seribu dan bahkan di Indonesia. Barangkali saja selama ini belum ada atau tidak pernah ditemukan penyakit karang karena tujuan khusus penelitian tentang penyakit karang tersebut belum ada sehingga walaupun sering melakukan penyelaman di berbagai lokasi, tetapi bukan untuk penelitian penyakit karang.

Berbeda dengan pengalaman penulis selama mengikuti kursus Coral disease and others marine organismedi Florida, sebagian besar BBD menyerang karang dari kelompok massive seperti terlihat pada Gambar 6.

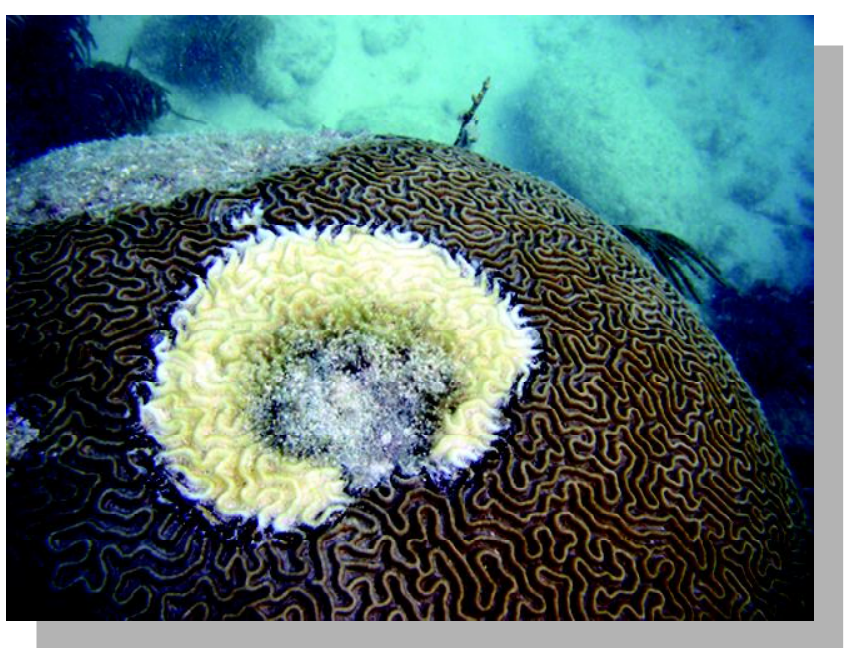

Gambar 6. Penyakit karang black band disease menyerang karang kelompok massive di Florida (Foto: Ofri Johan)

\section{Pengelolaan Penyakit Karang}

Manajemen penyakit di laut merupakan sesuatu hal yang baru, belum banyak berkembang dan dilakukan di dunia sekalipun. Manajemen secara tradisional saat ini yang sudah ada untuk mengontrol penyakit manusia dan hewan di antaranya karantina, seleksi, vaksinasi, dan pendidikan. Namun hanya karantina dan pendidikan yang merupakan pilihan yang tepat saat ini untuk penyakit karang, tetapi masih jarang dilakukan. Hal ini terjadi karena kita harus menyadari perbedaan pengelolaan antara sistem yang ada di laut dan darat untuk pelaksanaan manajemen penyakit karang. Pada perairan laut mendukung banyak dan beragamnya ditemukan komunitas mikrobiologi yang dapat berdampak negatif pada hewan di dalamnya. Namun banyak juga mikroba yang patogen atau potensial menyebabkan penyakit yang belum diketahui. Karena perairan laut bisa menampung 
komunitas mikroba yang sangat banyak, sistem di laut disadari sebagai lebih terbuka dan saling berhubungan dengan sistem yang ada di darat. Kemudian ditambahkan lagi karena tidak lengkapnya pengetahuan tentang karang, penyakitnya, kemampuan bertahan dan dampak tekanan faktor lingkungan pada kesehatan karang, permasalahan ini sebagai tantangan dalam pengembangan dalam manajemen di masa akan datang (Raymundo et al., 2008).

Namun mengingat dampak dari penyakit karang dapat menurunkan populasi karang sehingga dibutuhkan pengembangan manajemen bersamaan dengan investigasi penyakit karang secara saintifik. Meskipun secara ilmu pengetahuan masih belum berkembang tentang manajemen ini, ada beberapa langkah secara praktis di mana para manajer karang dapat melakukan pengaturan untuk meminimalkan dampak penyakit karang tersebut. Persepsi saat ini bahwa penyakit karang tidak bisa diatur adalah tidak benar dan para manajer diharapkan sanggup mengembangkan dan menguji opsi dalam mengontrol penyebaran penyakit karang. Namun uji coba ini seharusnya dilakukan dengan perencanaan yang hati-hati, karena banyak pilihan dalam manajemen yang harus diuji melalui desain eksperimen yang cocok dan hasilnya nanti bisa sesuai dengan yang diharapkan.

Manajemen sumberdaya alam harus berdasarkan perkembangan ilmu pengetahuan. Dengan demikian informasi ilmu pengetahuan harus diarahkan dan dikomunikasikan secara efektif sehingga membantu dalam pengambilan keputusan. Seiring perkembangan ilmu pengetahuan dan isu manajemen yang dibutuhkan cepat, penyakit karang difokuskan pada usaha penelitian secara global di dunia yang akan menghasilkan banyak informasi penting.

Ada beberapa database yang dapat diakses lewat internet, yang berisi dari beberapa tipe informasi dari penyakit karang. Database sangat penting dalam mensitesa informasi dari berbagai sumber dan percaya pada informasi yang akurat yang tersedia pada website tersebut. Perlu juga dibentuk jaringan antar lembaga, peneliti dan manajer yang berdedikasi dan memenuhi standar kualifikasi untuk membantu, memberikan informasi dan saran dengan ditemukannya permasalahan di masing-masing negara di dunia (Raymundo et al., 2008).

Strategi manajemen penyakit karang harus berkembang sebagai hasil dari pengujian secara hati-hati dan teliti yang kemudian hasilnya dilaporkan. Seperti diutarakan sebelumnya, metode tradisional dari pemilihan dan vaksinasi dari pengontrol penyakit karang saat ini telah dibatasi penggunaannya dalam manajemen penyakit karang. Karang tidak sama dengan hewan liar lainnya, karang tidak bergerak sehingga apabila sekali koloni mendapat infeksi penyakit pada suatu lokasi akan menjadi lokasi yang tetap dan dapat dihitung dan dikunjungi berulang kali (dan potensi dilakukan perlakuan kalau ada metode yang cocok). Lebih jauh lagi karang dapat ditumbuhkan kembali di atas skeleton (karang mati) melalui penempelan larva baru. Pada cara ini, fungsi karang seperti tanaman yang dapat difragmen menjadi koloni karang baru. Dengan mengetahui karakteristik ini dapat membantu manejer untuk berpikir dan mengembangkan strategi manajemen bagi karang dan hewan sesil lain sebagai hewan bentik. Pengalaman dengan adanya literatur tentang budidaya dan penyakit tanaman dapat menyediakan petunjuk dalam manajemen penyakit karang.

Seperti disebutkan sebelumnya, pembuktian penyebab penyakit karang adalah sulit, membutuhkan proses yang panjang, meliputi bidang manajer dan laboratorium atau lokasi penelitian. Langkah manajemen pertama yang harus diambil yaitu mengembangkan ilmu pengetahuan dari penyakit dan kesepakatan pernyataan penyakit saat ini pada area manajemen (seperti mengetahui kondisi normal saat ini, level apa, dalam komunitas karang). Dengan memahami kondisi saat ini yang bisa mengakses bagaimana tingkatan kondisi penyakit normal dan potensinya pada peningkatan kematian karang.

Dengan demikian perlu monitoring berkelanjutan untuk mendapatkan series data untuk melihat cara yang terbaik dalam manajemen penyakit karang. Respons terhadap fenomena alam seperti pemanasanan permukaan air laut atau ancaman secara periodik pemakan karang seperti diamati pada monitoring yang dapat terjadi pada luasan area sehingga diketahui daerah yang memiliki daya tahan yang kuat atau lemah dari dampak tersebut. Hal ini disadari kebijakaan yang baik untuk mengidentifikasi khususnya lokasi yang mudah terkena dampak penyakit karang (dan juga memiliki kemampuan untuk pemulihan dan bertahan) untuk meningkatkan proteksi dan manajemen. Kumpulan data yang diperoleh dari monitoring juga dapat digunakan untuk perubahan kebijakan (seperti panduan pengembangan daerah pesisir) dan untuk mengakses dampak dari bahaya pendaratan kapal di daerah terumbu karang dan tumpahan minyak.

Hubungan yang jelas antara penyakit karang dan masuknya bahan antropogenik spesifik dapat digunakan sebagai acuan perlunya untuk meningkatkan kualitas perairan, khususnya pada ekonomi lokal yang tergantung pada penyelaman turis dan kesehatan terumbu karang. Pada saat ini banyaknya infeksi syndrome dari karang 
disebabkan oleh bakteri oppurtunistik dengan beberapa genus vibrio, yang merupakan bakteria yang umum di laut, di antara genus ini juga menyebabkan penyakit pada manusia buang air berlebihan seperti kolera (Vibrio cholera). Infeksi lain seperti brown band disease (BrB), skeletal eroding band (SEB), dan Caribbean ciliate infection (CCl) juga dapat menyerang karang. Pada kasus infeksi ini, opsi manajemen yang terbaik adalah untuk mengontrol atau mengurangi tekanan pada lingkungan yang meningkatkan kemampuan karang bertahan atau pemulihan dari infeksi penyakit.

\section{Upaya Pengendalian Penyakit Karang}

Pada suatu kejadian karang bisa berhasil hidup dari peristiwa bleaching dan pada kasus lain karang mengalami kematian akibat infeksi yang opurtunis karena daya tahan yang lebih rendah akibat stres karang bleaching. Pada kasus ini mengesankan karantina pada terumbu karang yang terserang penyakit yang akut baik bleaching atau penyakit karang sebagai opsi yang mungkin diambil. Terumbu karang dapat ditutup terhadap aktivitas manusia dengan melarang penyelam dan aktivitas snorkeling pada waktu tertentu. Usaha seperti ini berhasil dilakukan di Florida pada tahun 2003 selama terjangkitnya penyakit karang. Pada daerah terumbu karang di Florida Key ditutup bagi semua aktivitas manusia kecuali kegiatan penelitian dan investigasi selama 60 hari. Karena penyakit karang yang belum diketahui penyebabnya dapat menyerang kesehatan manusia. Kemudian tidak hanya penyelam merusak dan mematahkan koloni karang, tapi juga patogen dapat berpindah dari terumbu karang ke peralatan selam yang digunakan. Sebagaimana diketahui sangat banyak operator penyelaman yang melakukan penyelaman sepanjang hari sehingga sangat berbahaya Kalau terjadi kontaminasi pada alat selam yang mereka gunakan. Penutupan sementara dapat mengisolasi daerah terinfeksi dan mengurangi bahaya dari penyakit karang.

Kegiatan manajemen dapat mengurangi infeksi yang mungkin disebabkan oleh patogen. Sebagai contoh ada beberapa keberhasilan di dalam mengatur penyebaran penyakit black band disease (BBD) selama pemanasan dengan mengisap band menggunakan selang yang besar atau pompa. Tanah liat atau lem dompul dapat ditempelkan langsung pada bagian band. M etode ini dikenalkan pertama kali oleh Harold Hudson pada tahun 1986, yang kemudian banyak diadopsi oleh beberapa peneliti. Kalau tanah liat yang digunakan, semua filamen cyanobakteri harus dibuang. Tidak begitu lama filamen akan muncul di antara tanah liat. Dompul susah ditempelkan dengan baik apalagi kerja di bawah air, tetapi penempelan ini lebih permanen dan dengan efektif menghentikan pertumbuhan cyanobacterial yang menempel di skeleton karang. Hal ini juga berhasil pada penyakit karang yellow band disease, white plague, dan white band disease. Hasil awal menunjukkan bahwa perkembangan band menjadi lambat lebih pada 69\%kasus yang diamati. Kalau metode ini akan dilakukan harus dilaksanakan dengan ekstra hati-hati untuk mencegah menyebar cyanobacterial dan organisme lain yang terdapat dalam band disease terhadap karang di sekitarnya.

Eksperimen lain menunjukkan black band disease dapat dihilangkan dan rata kemunculan infeksi baru dapat diturunkan dengan memasukkan hewan herbivor urchin (bulu babi, Diadema antillarum) ke habitat di mana penyakit tersebut banyak ditemukan. Bulu babi akan memakan (grazing) sehingga akan menurunkan potensi kompetisi alga dengan karang, dengan demikian menurunkan kemungkinan luka yang akan mendorong invasi patogen, dengan langsung meninggalkan substrat di mana filamen cyanobacterial membutuhkan untuk penempelan.

Sementara antibiotik berhasil digunakan untuk mengobati infeksi pada manusia dan hewan lain, tetapi tidak direkomendasikan penggunaan antibiotik pada ekosistem laut yang terbuka dan khususnya karang.

\section{PENUTUP}

Penyakit karang dapat disebabkan oleh faktor abiotik di antaranya disebabkan oleh stres temperatur, sedimentasi, zat kimia, nutrien tidak seimbang, radiasi ultra-violet. Sementara penyebab dari faktor biotik seperti predasi, kompetisi dengan alga, terinfeksi penyakit. Perkembangan penelitian di luar negeri tentang penyakit karang sudah mulai berkembang dengan baik, namun untuk wilayah Indonesia belum ada institusi yang lebih mendalam melakukan penelitian dan apalagi manajemen penyakit karang. Perlu keterlibatan komunikasi global dan membangun jaringan dengan lembaga-lembaga yang sudah aktif di bidang penelitian dan penanganan dalam manajemen penyakit karang di Indonesia.

\section{DAFTAR ACUAN}

Croquer, A., Pauls, S.M., \& Zubillaga, A.L. 2003. White plague disease outbreak in a coral reef at Los Roques National Park, Venezuela. Rev. Biol. Trop., 51(4): 3945.

Gil-Agudelo, D.L., Smith, G.W., \& Weil, E. 2006. The white band disease type II pathogen in Puerto Rico. Rev. Biol. Trop. Int. J. Trop. Biol., Vol. 54(3): 59-67. 
Cervino, J.M., Hayes, R.L., Polson, S.W., Polson, S.C., Goreau, T.J., Martinez, R.J., \& Smith, G.W. 2004. Relationship of Vibrio Species Infection and Elevated Temperatures to Yellow Blotch/Band Disease in Caribbean Corals. Applied And Environmental Microbiology, p. 6855-6864.

Goreau, T.J., Cervino, J., Goreau, M., Hayes, R., Hayes, M., Richardson, L., Smith, G., DeMeyer, K., Nagelkerken, I., Garzon-Ferreira, J., Gil, D., Garrison, G., Williams, E.H., Bunkley-Williams, L., Quirolo, G., Patterson, K., Porter, J.W., \& Porter, K. 1998. Rapid spread of diseases in Caribbean coral reefs. Rev. Biol. Trop., 46(5): 157-171.
Yamashiro, H. 2004. Coral disease. Coral Reef of Japan. Edited by The Japanese Coral Reef Society and Ministry of the Environment. Ministry of the Environment of Japan, $356 \mathrm{pp}$.

Peter, E.C. 1997. Disease of coral reef organisme. Life and Death of Coral Reefs. [Eds. Birkeland, C]. Chapman $\&$ Hall, Dept. BC, $536 \mathrm{pp}$.

Raymundo, L.J., Couch, C.S., \& Harvel, C.D. 2008. Coral disease Handbook. Guidelines for Assessment, Monitoring and Management. Coral Reef Targeted and Capacity Building for Management Program, 121 pp.

Richardson, L.L. 1998. Coral diseases: what is really know? Trends Ecol. Evol., 13: 438-443. 